\title{
Patti MG, Herbella FA. Fundoplication After Laparoscopic Heller Myotomy for Esophageal Achalasia: What Type? J Gastrointest Surg. 2010 Sept.;14(9):1453-8
}

\author{
Marco G. Patti • Fernando A. M. Herbella
}

Received: 10 April 2011 / Accepted: 20 June 2011 /Published online: 13 August 2011

(C) 2011 The Society for Surgery of the Alimentary Tract

\section{Dear Editor,}

We would like to thank Dr. Pontone and his colleagues for their interest in our review paper ${ }^{1}$ and their letter to this esteemed journal. They raise some important questions that we will be glad to answer even though they are unrelated to the manuscript we wrote. Our goal was not to review the treatment of esophageal achalasia, but rather to assess the role of fundoplication after the myotomy, and to identify the best procedure that limits postoperative reflux while avoiding recurrent dysphagia.

Dr. Pontone et al. raise three points: (1) the superiority of the Dor fundoplication over the Toupet fundoplication, (2) the influence of previous endoscopic therapy on the outcome of the myotomy, and (3) the use of intra-operative endoscopy. There is no definite evidence that shows the superiority of the Dor fundoplication over the Toupet fundoplication. Since both procedures seem to be very similar in terms of clinical outcome and complications, the choice is based on surgeons' preference. Although we prefer an anterior wrap, others have excellent results with a posterior wrap. ${ }^{2}$

M. G. Patti · F. A. M. Herbella

Department of Surgery, University of Chicago,

Chicago, IL, USA

M. G. Patti $(\bowtie)$

Center for Esophageal Diseases,

University of Chicago Pritzker School of Medicine,

5841 S. Maryland Avenue, MC 5095, Room G 201,

Chicago, IL 60637, USA

e-mail: mpatti@surgery.bsd.uchicago.edu
Many studies have shown that previous therapy, either intra-sphincteric injections of botulinum toxin or pneumatic dilatation, makes the myotomy more difficult to perform because of the loss of the normal anatomic planes. In addition, the results are less predictable and often worse than those obtained in patients who have never been treated before the myotomy. ${ }^{3,4}$

We agree that intra-operative endoscopy may help identify the esophago-gastric junction, guiding the extent of the myotomy. ${ }^{5}$ However, with more experience, this step can be avoided in most cases.

\section{References}

1. Patti MG, Herbella FA. Fundoplication after laparoscopic Heller myotomy for esophageal achalasia: what type? J Gastrointest Surg. 2010;14:1453-1458.

2. Oelschlager BK, Chang L, Pellegrini CA. Improved outcome after extended gastric myotomy for achalasia. Arch Surg 200;135:902906.

3. Patti MG, Arcerito M, Feo C, Way LW. Effect of previous treatment on results of laparoscopic Heller myotomy for achalasia. Dig Dis Sci 1999;44:2270-2276.

4. Portale G, Costantini M, Rizzetto C, Guirroli E, Ceolin M, Salvador R, Ancona E, Zaninotto G. Long-term outcome of laparoscopic Heller-Dor surgery for esophageal achalasia: possible detrimental role of previous endoscopic treatment. J Gastrointest Surg. 2005;9:1332-1339.

5. Alves A, Perniceni T, Godeberge P, Mal F, Lévy P, Gayet B. Laparoscopic Heller's cardiomyotomy in achalasia. Is intraoperative endoscopy useful, and why? Surg Endosc. 1999;13:600603. 